\title{
《Review》 \\ Heat Stress Biomarker Amino Acids and Neuropeptide Afford Thermotolerance in Chicks
}

\author{
Vishwajit S. Chowdhury \\ Lab of Stress Physiology and Metabolism, Graduate School of Bioresource and Bioenvironmental Science, Division for \\ Experimental Natural Science, Faculty of Arts and Science, Kyushu University, Fukuoka 819-0395, Japan
}

\begin{abstract}
With global warming, heat stress is becoming a pressing concern worldwide. In chickens, heat stress reduces food intake and growth, and increases body temperature and stress responses. Although it is believed that young chicks do not experience heat stress as they need a higher ambient temperature to survive, our series of studies in young chicks showed that they are sensitive to heat stress. This review summarizes current knowledge on amino acid metabolisms during heat stress, with special emphasis on the hypothermic functions of L-citrulline (L-Cit) and Lleucine (L-Leu), and the functions of neuropeptide Y (NPY) in terms of body temperature and heat stress regulation in chicks. Amino acid metabolism is severely affected by heat stress. For example, prolonged heat stress reduces plasma L-Cit in chicks and L-Leu in the brain and liver of embryos. L-Cit and L-Leu supplementation affords thermotolerance in young chicks. NPY expression is increased in the brains of heat-exposed chicks. NPY has a hypothermic action under control thermoneutral temperature and heat stress in chicks. The NPY-sub-receptor Y5 is a partial mediator of the hypothermic action of NPY. Further, NPY stimulates brain dopamine concentrations and acts as an anti-stress agent in heat-exposed fasted, but not fed chicks. In conclusion, young chicks can serve as a model animal for the study of heat stress in chickens. L-Cit, L-Leu, and NPY were identified as biomarkers of heat stress, with the potential to afford thermotolerance in chicks.
\end{abstract}

Key words: chicks, L-citrulline, L-leucine, neuropeptide Y, thermotolerance

J. Poult. Sci., 56: 1-11, 2019

\section{Introduction}

The earth's surface temperature in 2017 ranked the second warmest since 1880 according to an analysis by the National Aeronautics and Space Administration, USA (NASA, 2017). The potential of such increasing ambient temperature to enhance heat stress issues is a serious concern globally. Heat stress threatens the commercial poultry sector in tropical and sub-tropical countries as well as in temperate countries exposed to summer heat waves. It can reduce food intake, live weight gain, and food efficiency in broilers (Howlider and Rose, 1987; Siegel, 1995; Niu et al., 2009; Azad et al., 2010), and can affect egg production in laying hens (Marsden et al., 1987; Peguri and Coon, 1991; Yahav et al., 2000; Sterling et al., 2003; Lin et al., 2004; Franco-Jimenez and Beck, 2007; Ajakaiye et al., 2010). In chickens, high ambient temperature (HT) can lead to an increase in deep body

Received: February 19, 2018, Accepted: March 16, 2018

Released Online Advance Publication: April 25, 2018

Correspondence: Vishwajit Sur Chowdhury, Ph.D., Lab of Stress Physiology and Metabolism, Faculty of Arts and Science, Kyushu University Fukuoka 819-0395, Japan. (E-mail: vc-sur@artsci.kyushu-u.ac.jp)

ORCID ID: orcid.org/0000-0001-6709-2788 (rectal) temperature (Yahav and Hurwitz, 1996) and may cause heat stress (Bartlett and Smith, 2003; Soleimani et al., 2010). It is generally believed that young chicks are not prone to heat stress as they need HT for their survival. However, limited attention has been paid to young layer chicks with respect to heat stress issues, and several of our recent studies suggested that both layer and broiler chicks are sensitive to HT (Chowdhury et al., 2012a, b, 2014, 2017; Ito et al., 2014, 2015; Han et al., 2017, 2018, Eltahan et al., 2017). When young chicks were exposed to $35^{\circ} \mathrm{C}$ for $3 \mathrm{~h}$, their food intake decreased and their rectal temperature increased (Bahry et al., 2017). Further, 3- and 5-day-old chicks were less sensitive to heat stress $\left(40^{\circ} \mathrm{C}\right.$ for $\left.4 \mathrm{~h}\right)$ when the control thermoneutral temperature $(\mathrm{CT})$ was $30^{\circ} \mathrm{C}$, while chicks of 7 days or older were sensitive to heat stress (Chowdhury et al., 2012b).

Mammals are also very sensitive to heat stress. For example, like chickens, pigs do not have functional sweat glands (Ensminger et al., 1990). In pigs, thermoregulatory responses for avoiding heat stress are activated above $25^{\circ} \mathrm{C}$ (Quiniou and Noblet, 1999). Heat stress increases rectal temperature in swine (Dou et al., 2017), cattle (Kamal et al., 2018), and chickens (Chowdhury et al., 2014). Further, a 
significant reduction in voluntary feed intake is generally observed in swine (Dou et al., 2017), cattle (Kamal et al., 2018), and chickens (Chowdhury et al., 2012) during heat stress. This response is considered the main adaptation mechanism for reducing metabolic heat production (Nyachoti et al., 2004), which has negative effects on growth performance in mammals (D'Allaire et al., 1996; Kamal et al., 2018) and chickens (Mashaly et al., 2004).

Amino acids play important roles in growth $(\mathrm{Li}$ and $\mathrm{Wu}$, 2018) and might be critical in controlling food intake (Tran et al., 2015, 2016) and behavior (Kabuki et al., 2011; Ikeda et al., 2014; Tran et al., 2015). Several free amino acids were found to be significantly increased in the blood, brain, and skeletal muscle of chicks within 15 or 30 min of exposure to HT $\left(35^{\circ} \mathrm{C}\right.$; Ito et al., 2014); however, most of these amino acids in the brain and plasma declined when chicks were exposed to prolonged HT $\left(35^{\circ} \mathrm{C}\right.$ for $48 \mathrm{~h}$; Chowdhury et al., 2014). Based on these findings, we subsequently found that L-citrulline (L-Cit), which was increased in the plasma of chicks following short-term heat exposure and decreased after long-term heat exposure, has a hypothermic function when administered orally in chicks (Chowdhury et al., 2015, 2017). In addition, thermal manipulation (TM) during embryogenesis resulted in a reduction in brain and liver concentrations of L-leucine (L-Leu). Interestingly, in ovo feeding of L-Leu affords thermotolerance in broiler chicks (Han et al., 2017, 2018). Thus, certain amino acids that decrease or increase in chicks depending on the length of exposure to HT and its magnitude may serve as biomarkers of heat stress.

The central nervous system is thought to be a critical center of behavioral motivation. Therefore, brain function has been meticulously studied. Hypothalamic neuropeptides are important in the regulation of food intake (Furuse, 2007; Cline and Furuse, 2012) and stress (Carrasco and Van de Kar, 2003; Madaan and Wilson, 2009; Alldredge, 2010; Schank et al., 2012; Lin, 2012; Catena-Dell'Osso et al., 2013). Hypothalamic neuropeptides are also important in the regulation of body temperature. The thermoregulatory center is widely reported to be located in the hypothalamus. In particular, the hypothalamic preoptic area (POA) contains neurons that are sensitive to warmth and trigger hypothermia (Hammel, 1968). Tan et al. (2016) reported that brain-derived neurotrophic factor and pituitary adenylate cyclase-activating polypeptide have important roles in body temperature regulation in the POA. Recent studies have focused on hypothalamic neuropeptide Y (NPY) in an attempt to unravel its role in the regulation of body temperature and heat stress in chicks (Bahry et al., 2017; Eltahan et al., 2017).

In this review, I will summarize the effects of heat stress on amino acid metabolism, with special emphasis on the hypothermic functions of L-Cit and L-Leu. Moreover, the functions of NPY in terms of body temperature and heat stress regulation in chicks will be described.

\section{Amino Acid Metabolism in Embryos and Chicks under Heat Stress}

Twenty amino acids are commonly found in animal pro- teins. In growing chicks, 11 of these (arginine (Arg), histidine, isoleucine, leucine (Leu), lysine, methionine, phenylalanine, threonine, tryptophan, valine, and glycine) are essential amino acids, while the others are nonessential amino acids (Banerjee, 1998). These 20 amino acids which have codon, cannot be stored as free molecules and must follow anabolic routes to peptides, proteins, hormones, and other bioactive molecules or catabolic pathways to glucose, ketone bodies, or uric acids in birds. Heat stress causes catabolic activity to increase in organisms (Maeda et al., 2017) to provide energy to counter the heat stress. Protein turnover has a high energy cost: it requires $4.5-7 \mathrm{~mol}$ of ATP per mole of peptide bond formed and 1-2 mol of ATP per mole of peptide bond breakage (Bequette, 2003). Therefore, the increase or decrease in free amino acids that occurs under heat stress (Ito et al., 2014, 2015; Chowdhury et al., 2014; Eltahan et al., 2017) can be assumed to be the result of catabolic processes. Inter-organ amino acid flux is important for determining the sites where amino acids are ultimately used (Seal and Parker, 2000). All tissues contain enzymes for amino acid catabolism and synthesis, but their expression and activity levels vary depending on the metabolic needs or functions of the tissue. Catabolism involves deamination/ deamidation reactions followed by either reamination of the resulting carbon skeleton to form non-essential amino acids, or channeling of the carbon skeleton into the tricarboxylic acid cycle, where it is oxidized, channeled towards gluconeogenesis via pyruvate carboxylase, or converted from pyruvate into acetate for fatty acid synthesis. Amino acids act not only as constituents of proteins but also as regulators of various physiological and/or pharmacological functions. Substantial attention has been paid to the regulation of physiology and behavior, including stress responses (Asechi et al., 2006; Hamasu et al., 2009a, b; Kurauchi et al., 2010; Kurata et al., 2011; Erwan et al., 2014). Bird diets have been supplemented with amino acids, especially essential amino acids, to overcome the problems caused by heat stress (Mendes et al., 1997; Rose and Uddin, 1997; Brake et al., 1998; Daghir et al., 2003; Willemsen et al., 2011; Dai et al., 2012). Although there have been fewer investigations into the changes in amino acid concentrations in chickens under heat stress, Ito et al. (2014) reported that while several free essential as well as nonessential amino acids increased in the blood, brain, and skeletal muscle following short-term heat stress (less than $30 \mathrm{~min}$ ), the levels of some other amino acids were significantly reduced.

The reason for the increases in various amino acids is still unknown, but it is possible that the increased plasma amino acids may have been derived from proteins from the liver or some other soft tissues that are more labile than myofibrillar proteins in skeletal muscle. Interestingly, the levels of free amino acids induced during short-term heat stress $\left(35^{\circ} \mathrm{C}, 15\right.$ or $30 \mathrm{~min}$ ) were nearly inversely correlated with those induced by long-term heat stress $\left(35^{\circ} \mathrm{C}, 24\right.$ or $48 \mathrm{~h}$ ), upon which most of the free amino acids were reduced. For instance, tryptophan, Cit, and Orn were reduced in the plasma of chicks exposed to long-term heat stress (Chowdhury et al., 
2014), whereas they increased during short-term heat stress (Ito et al., 2014).

Various free amino acids in the chick brain and breast muscle are also altered upon heat exposure. Interestingly, the free amino acids in the brain and skeletal muscle were mostly different from those found in the plasma. All the altered free amino acids in the various parts of the brain, except for proline and cystathionine, were different. These findings indicate that alterations in free amino acid contents may be tissue-specific, which is in accordance with the fact that enzymatic activity related to amino acid metabolism and protein synthesis is tissue-specific. In chick breast muscle, the concentration of 3-methyl histidine, a marker of proteolysis (Young and Munro, 1978; Nishizawa, 1983), was significantly $(P<0.05)$ declined upon short-term heat stress (Ito et al., 2014), suggesting that protein degradation was reduced in this condition. As protein synthesis and degradation are balanced in the body, it can be predicted that protein synthesis would decrease and the pool of free amino acids in the tissue would increase during heat stress.

TM is applied during embryogenesis to increase the incubation temperature, resulting in the acquisition of thermotolerance by neonatal chicks (Moraes et al., 2003) and chickens (Loyau et al., 2014) under HT. Recently, we found that several amino acids, including Leu, lysine, and phenylalanine, were significantly reduced in the brain and liver in embryos that were exposed to TM (Han et al., 2017). In summary, amino acid metabolic activity can be affected by heat stress in embryos and chicks.

\section{Hypothermic Amino Acids in Heat-Exposed Chicks}

Intracerebroventricular (i.c.v.) administration of L-Cit, LOrn, and L-Arg did not cause a reduction in rectal temperature (Chowdhury et al., 2015). However, orally administered L-Cit, but not L-Arg or L-Orn, did reduce rectal temperature (Chowdhury et al., 2015). Further, it caused a significant $(P<0.0001)$ reduction in rectal temperature in heatexposed chicks, comparable to that observed in non-heatexposed control chicks (Chowdhury et al., 2017). These findings suggested L-Cit has a hypothermic function.

In mammals, nearly all L-Arg supplied via the food is withdrawn from the portal blood by the liver for conversion to urea (Curis et al., 2005). However, L-Cit can bypass the liver, as the liver is unable to uptake L-Cit from the portal circulation (Windmueller and Spaeth, 1981). This bypassed $\mathrm{L}-\mathrm{Cit}$ is converted to L-Arg in the kidneys and is released into the blood to make it available for the whole body. Birds lack carbamyl phosphate synthetase, one of the enzymes of the urea cycle necessary for the synthesis of L-Cit from L-Orn (Tamir and Ratner, 1963). Hence, they cannot synthesize LCit or L-Arg from L-Orn, although they can synthesize L-Orn from L-Arg (Suenaga et al., 2008). Fig. 1 shows the L-Cit metabolic pathways in chickens.

Nitric oxide (NO), produced during the conversion of L-

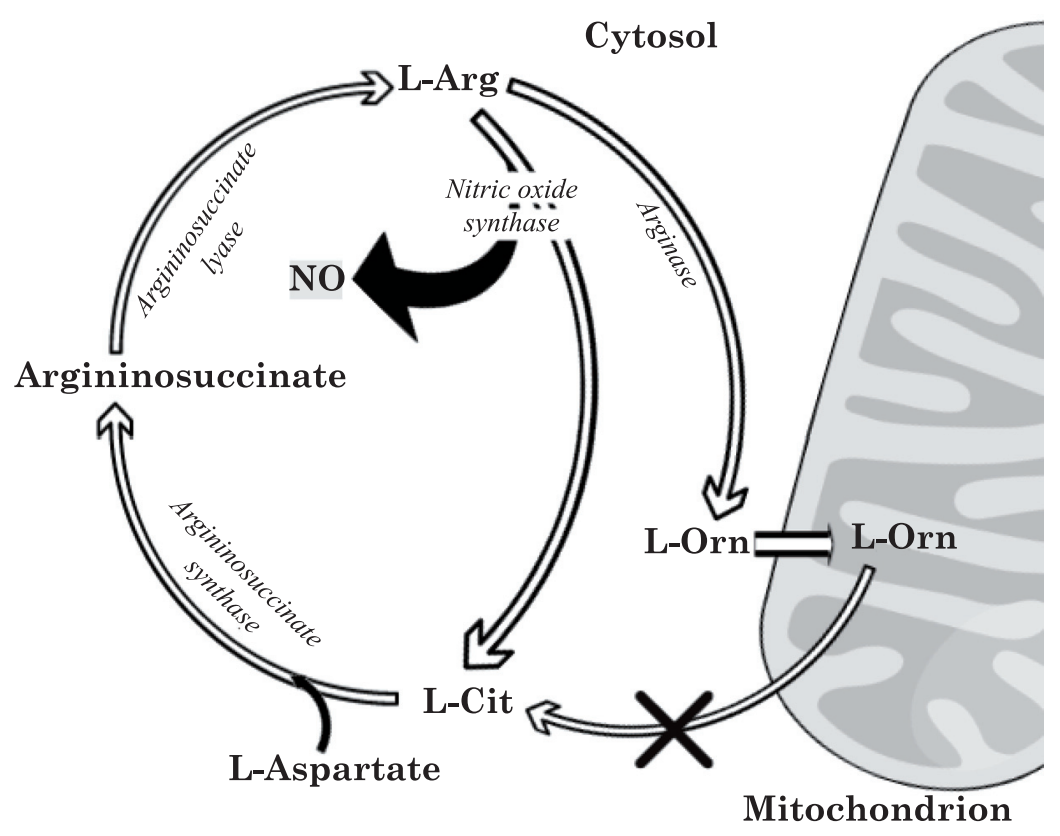

Fig. 1. Diagram showing the L-Cit metabolic pathway. Enzymes for all steps of the biochemical pathway are shown. Notably, chickens lack carbamoyl phosphate synthetase, which is necessary for the synthesis of L-Cit from L-Orn (Tamir and Ratner, 1963). Therefore, chickens cannot synthesize L-Cit from L-Orn (indicated with a cross). L-Arg, L-arginine; L-Cit, L-citrulline; NO, nitric oxide. This image was reprinted from Journal of Thermal Biology, 69: 163-170 with permission from Elsevier as the authors' right. 
Arg to L-Cit by the enzyme NO synthase (Palmer et al., 1987), may act as a hypothermic agent in chicks, and thermoregulation has been proposed as one of the main physiological functions of NO (Szabo, 1996). However, we recently found that NO may not be the main factor in L-Citdependent hypothermia and thermotolerance (Chowdhury et al., 2017). Plasma glucose has been found to be lower in LCit-treated chicks at both 30 and $90 \mathrm{~min}$. Somehow, L-Cit causes an abrupt reduction in plasma glucose, and this may be connected in some way with hypothermia (Chowdhury et al., 2017). Hypothermia reportedly is related to hypoglycemia in mammals and amphibians. In mammals, an acute reduction in circulating glucose normally causes the body temperature to decrease (Mayer-Gross and Berliner, 1942; Freinkel et al., 1972; Buchanan et al., 1991). Similarly, hypoglycemia causes hypothermia and is considered to be an adaptive response in rats (Buchanan et al., 1991). Doerfler et al. (1998) reported that hypoglycemia occurred in turkeys when hypothermia was detected. It is worth mentioning here that the blood glucose level may be connected in some way with the high body temperature in birds. For example, the blood glucose level in domestic canary (Serinus canaria domestica), whose body temperature is $42^{\circ} \mathrm{C}$, is $\sim 236 \mathrm{mg} / 100$ $\mathrm{m} l$. The common swift (Apus apus), a medium-sized bird, has a blood glucose level of $\sim 305 \mathrm{mg} / 100 \mathrm{ml}$ and a body temperature of $44^{\circ} \mathrm{C}$. The house sparrow (Passer domesticus) has $288 \mathrm{mg} / 100 \mathrm{ml}$ blood glucose and a body temperature of $41.4^{\circ} \mathrm{C}$, which is close to that of chickens, whose body temperature is $41.5^{\circ} \mathrm{C}$ and blood glucose $\sim 260 \mathrm{mg} / 100 \mathrm{~m} l$ (Flindt, 2002). In comparison, the blood glucose level in humans is $\sim 100 \mathrm{mg} / 100 \mathrm{~m} l$ and body temperature $37^{\circ} \mathrm{C}$. Further experiments are needed to clarify this potential link. We can conclude that NO production may not contribute significantly to L-Cit-dependent hypothermia; instead, hypoglycemia appears to be one of the factors that play a role in this process. Because oral administration of $\mathrm{L}$-Cit affords thermotolerance in chicks, this amino acid might be a novel nutritional candidate for enabling poultry to cope with heat stress.

Leu is significantly reduced in the embryonic brain and liver as a result of TM. Supplementation of L-Leu through in ovo feeding led to hypothermia in both male and female chicks at hatching; however, females could better reduce their body temperature at hatching than males (Han et al., 2017). Metabolic activity was significantly $(P<0.05)$ increased following in ovo administration of L-Leu during embryogenesis. Lipid metabolism in embryos and in male but not female chicks significantly $(P<0.05)$ increased as a result of in ovo feeding of L-Leu. The enhanced lipid metabolic rate might have been the result of increased mitochondrial activity, as Liang et al. (2014) reported that L-Leu and its metabolites $[\alpha$-ketoisocaproate and $\beta$-hydroxy- $\beta$ methylbutyrate] are able to stimulate mitochondrial biogenesis and oxidative activities. Levels of plasma tryacylglycerol (TG), non-esterified fatty acids (NEFA), and ketone bodies were higher in L-Leu-treated male chicks under heat stress than in heat-exposed control chicks. Broiler chicks would benefit from L-Leu in ovo feeding because fat produces less heat, and the beneficial effects of fats in hot-weather feeding programs are well documented (Daghir, 2008). Han et al. (2018) have suggested that L-Leu-dependent prenatal imprinted lipid metabolic memory might have a genderspecific metabolic response to active lipid metabolic functions. Methylation or acetylation on the ' $Z$ ' chromosome as a result of in ovo feeding of L-Leu might have a stronger influence in males (ZZ) than in females (ZW), explaining the differences in lipid metabolism that afford gender-specific thermotolerance. Further research is needed to clarify this matter.

The high level of plasma ketone bodies found in chicks fed L-Leu in ovo indicates that the liver generates and releases more ketone bodies into the bloodstream (Han et al., 2018). Consequently, there might be increased demand for acetyl$\mathrm{CoA}$ in the liver, which might in turn stimulate the $\beta$ oxidation of fatty acids to produce more acetyl-CoA (Fig. 2). Unlike fatty acids, ketone bodies can cross the blood-brain barrier to provide energy to the brain when glucose is limited (Botham and Mayes, 2015). Fatty acid oxidation is highly exergonic in comparison with glucose oxidation, yielding numerous ATPs (Voet and Voet, 1995). The high levels of plasma NEFA and TG might support the lipid metabolism and ketogenesis that take place in the liver, similar to the findings during embryogenesis. Yahav (2015) suggested that reduced energy investment in high meat-producing broilers could be the reason for hyperthermia under heat stress; thus, the greater availability of energy produced by lipid metabolism in male chicks injected with L-Leu might be beneficial by affording thermotolerance under heat stress. In summary, in ovo feeding of L-Leu stimulates $\mathrm{O}_{2}$ consumption, HP, and lipid metabolism during embryogenesis, possibly causing a prenatal sex-specific metabolic imprinting to activate lipid metabolism in male, but not female broiler chicks under heat stress. Future study is needed to reveal the molecular mechanisms by which sex-dependent L-Leu activity confers thermotolerance.

\section{Neuropeptide Expression in Heat-Exposed Chicks}

Heat stress causes profound alterations at the cellular level (Morera et al., 2012). These alterations include changes in gene expression and biochemical adaptation responses, and are characterized by metabolic reprogramming of cells (Lindquist, 1986). Brobeck (1960) reported that hypothalamic neurons are able to perceive body temperature increases and as a result, influence the cells that are responsible for controlling food intake. Neuropeptides are important in the regulation of food intake in chicks (Cline and Furuse, 2012). For example, central injection of ghrelin has been found to inhibit food intake in birds (Furuse et al., 2001; Saito et al., 2002). A significant increase in brain ghrelin mRNA expression has been observed in layer chickens chronically exposed to heat $\left(31 \pm 1.5^{\circ} \mathrm{C}, 7\right.$ days) (Song et al., 2012). Thus, heat stress might upregulate anorexigenic peptide expression, which in turn suppresses food intake. In an attempt to verify this, first we examined the mRNA expres- 


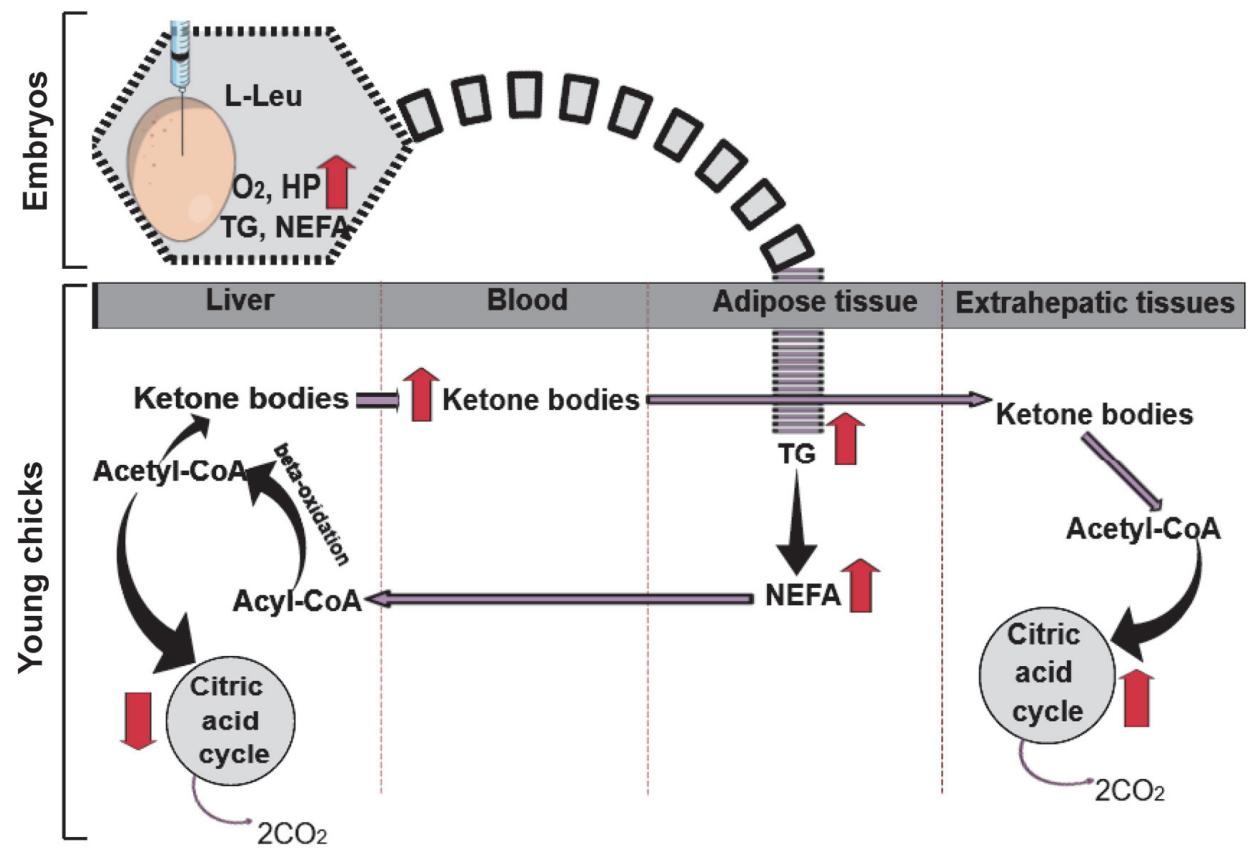

Fig. 2. Schematic overview of a possible imprinting in the lipid metabolism as a result of in ovo feeding of L-Leu between the embryonic and young stages in broiler chicks. The broken curved line shows a possible imprinting of lipid metabolic memory from the embryo to the young chick. Arrows indicate the progression $(\rightarrow)$, increase $(\uparrow)$, or decline $(\downarrow)$ in metabolites and metabolic processes. L-Leu, L-leucine; TG, tryacylglycerol; NEFA, non-esterified fatty acid; $\mathrm{HP}$, heat production; $\mathrm{O}_{2}$, oxygen; $\mathrm{CO}_{2}$, carbon dioxide.

sion of a number of anorexigenic neuropeptide genes, including pro-opiomelanocortin (POMC)-derived melanocortin peptides (Kawakami et al., 2000; Honda et al., 2012), cholecystokinin (CCK; Furuse et al., 2000), ghrelin (Furuse et al., 2001), and corticotropin-releasing hormone (CRH; Furuse et al., 1997b), in the acute heat-exposed chick brain. Second, we examined the orexigenic neuropeptides NPY (Kuenzel et al., 1987; Kuenzel and McMurtry, 1988; Furuse et al., 1997a) and gonadotropin-inhibitory hormone (GnIH, Tachibana et al., 2005; McConn et al., 2014, 2016). The abundant amounts of POMC, CCK, ghrelin, and CRH precursor mRNAs were not affected by heat stress $\left(40^{\circ} \mathrm{C}, 5 \mathrm{~h}\right)$. However, diencephalic NPY and GnIH mRNA expression was increased by heat stress in chicks (Chowdhury et al., 2012a; Ito et al., 2015). Surprisingly, when food intake was also suppressed, there was no significant alteration in the plentiful supply of anorexigenic neuropeptides in the acute heat-exposed chick brain (Ito et al., 2015). Interestingly, however, hypothalamic NPY precursor mRNA expression was upregulated when food intake was suppressed under heat stress. Similarly, we observed elevated expression of hypothalamic $\mathrm{GnIH}$ precursor mRNA in heat-exposed $\left(35 \pm 1{ }^{\circ} \mathrm{C}\right.$, 24 or 48 h) chicks (Chowdhury et al., 2012a). We theorized that the increased $\mathrm{GnIH}$ expression could be a consequence of food-intake suppression during heat stress (Chowdhury et al., 2012a), because Boswell et al. (1999) demonstrated that food restriction in growing broilers was associated with an increase in the steady-state abundance of NPY mRNA in the hypothalamus. However, alternative functions of NPY and $\mathrm{GnIH}$ were considered, as reduced food intake is a physiological adaptive mechanism of chicks experiencing heat stress. Hence, it was subsequently found that in addition to their role in food-intake regulation, NPY and GnIH play major roles in stress regulation.

\section{Anti-Stress and Hypothermic Functions of NPY in Heat-Exposed Chicks}

It has been suggested that in mammals, NPY is an antistress agent (Heilig, 2004; Kormos and Gaszner, 2013; Reichmann and Holzer, 2016; Sabban et al., 2016) with a neuroprotective function (Malva et al., 2012), and that NPY can affect the concentration of monoamines in the brain. For example, central administration of NPY increased extracellular dopamine (DA) and its metabolites, norepinephrine (NE), 3, 4-dihydrooxyphenylacetic acid, and homovanillic acid (HVA), but did not affect serotonin (5-HT) or 5-hydroxyindoleacetic acid concentrations in rats (Matos et al., 1996). However, few studies have evaluated monoamine changes, or the regulatory influence of NPY on these changes, during heat stress. Recently, we reported that NPY does not in- 
fluence rectal temperature in fed chicks. However, rectal temperature did change after i.c.v. injection of NPY in fasted chicks (Bahry et al., 2017). NPY caused a significant $(P<$ $0.001)$ increase in food intake under both $\mathrm{CT}$ and heat stress. Central NPY resulted in a significant decline in 5-HT $(P<$ $0.05)$ concentrations; however, 3-methoxy-4-hydroxyphenylglycol and HVA were significantly $(P<0.05)$ increased in fed chicks. Interestingly, a high dose of NPY significantly $(P<0.05)$ increased diencephalic DA concentrations in fasted
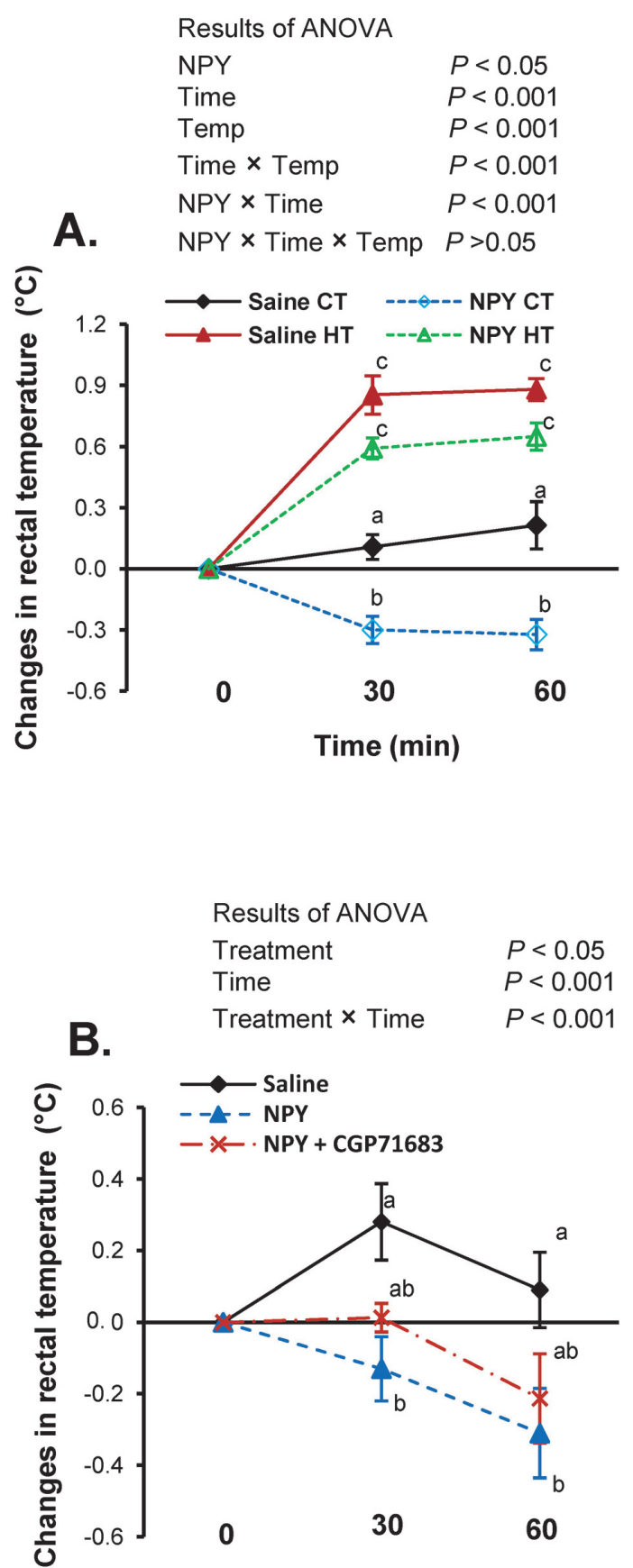

Time (min) chicks. Plasma NE and epinephrine (E) increased in chicks treated with NPY only under heat stress. NPY has been shown to reduce body temperature in neonatal chicks (Tachibana et al., 2006) and mammals (Szekely et al., 2004). NPY does not reduce rectal temperature in fed chicks but it does significantly reduce rectal temperature in fasted chicks under CT, but not under heat stress. However, food intake may have caused increased metabolic heat production, and this in turn might have masked an NPY-dependent reduction in body temperature because the metabolic rate affects body temperature (Webb, 1997). Furthermore, the hypothermic function of NPY under heat stress might be masked by norepinephrinergic activity because the sympathetic nervous system is stimulated under stress (Cockrem, 2007; Wang et al., 2013), and this could lead to an increase in body temperature (Szekely et al., 2004). Bahry et al. (2017) showed that NE and E concentrations were increased, while corticosterone levels were decreased in the plasma of fasted chicks under heat stress. Zhang et al. (2003) reported that central administration of NE led to a reduction in plasma corticosterone. Thus, it is possible that NPY and NPYdependent increases in NE reduced the plasma corticosterone levels under heat stress (Bahry et al., 2017). This would be consistent with an anti-stress effect of NPY in chicks.

Eltahan et al. (2017) reported that NPY causes hypothermia under $\mathrm{CT}$ as well as under heat stress in fasted chicks (Fig. 3A). I.c.v. injection of NPY significantly $(P<0.05)$ decreased the rectal temperature in fasted chicks under both CT and HT. The mRNA expression of NPY-sub receptors (NPYSRs) -Y5, -Y6, and -Y7 significantly $(P<0.05)$ increased in the brain following NPY injection under both CT and HT. The NPY-induced decline in rectal temperature was significantly $(P<0.05)$ suppressed by coinjection of CGP 71683 (Fig. 3B), an NPYSR-Y5 antagonist. Plasma glucose was significantly $(P<0.05)$ reduced by NPY i.c.v. injection. Central NPY also reduced plasma corticosterone levels under heat stress.

NPYSRs carry out specific functions related to the stress response. For example, NPYSR-Y1 brings about an anxiolytic effect, whereas NPYSR-Y2 mediates anxiogenic functions (Reichmann and Holzer, 2016). The expression of

Fig. 3. Effects of NPY and CGP71683 on rectal temperature in chicks. (A) Rectal temperature in fasted chicks following central injection of NPY $(375 \mathrm{pmol})$ or saline under control thermoneutral temperature (CT: 30土 $1^{\circ} \mathrm{C}$ ) or high ambient temperature (HT: $35 \pm 1^{\circ} \mathrm{C}$ ) for $1 \mathrm{~h}$. (B) Rectal temperature in chicks following central injection of NPY (375 pmol), saline or NPY (375 pmol) plus CGP 71683 (3750 pmol) under CT for $1 \mathrm{~h}$. Different letters indicate significant differences at $P<0.05$ between groups. Values are the mean \pm SEM of $12-15$ chicks in A and 8-10 chicks in B. This image was reprinted from Physiological Reports, 5(23): e13511. 69 with permission from Wiley Periodicals, Inc. on behalf of the Physiological Society and the American Physiological Society Wiley as the authors' right. 
NPYSRs-Y5, -Y6, and -Y7, but not -Y1, -Y2, and -Y4, is stimulated by NPY, which indicates that the hypothermic functions of NPY are mediated by all or any of these receptors. The finding by Eltahan et al. (2017) that coinjection of CGP71683 with NPY slightly lessens NPY-induced hypothermia suggests that NPYSR-Y5 is partially, but not entirely, involved in hypothermia. The functions of NPYSRsY6 and -Y7 in chickens remain unknown. There are currently no antagonists are available for NPYSRs-Y6 and -Y7. Previous reports (Boswell et al., 1998; He et al., 2016; Gao et al., 2017) have indicated that the mRNA expression patterns of NPY and its receptors closely resemble those of protein expression; however, further analysis of such correlation will be needed in future.

Plasma glucose is lower in NPY-treated chicks, and this might be a result of the anabolic function of NPY. Hypoglycemia is a well-known phenomenon that occurs concomitantly with hypothermia in mammals (Buchanan et al., 1991) and amphibians (Branco, 1997; Rocha and Branco, 1998), as discussed above. Thaxton et al. (1974) reported that oral administration of glucose increased the body temperature of chicks that were exposed to a cold environment and the authors proposed the involvement of carbohydrate metabolism in the physiological regulation of body temperature. Kuenzel and McMurtry (1988) reported that central injection of NPY increased plasma insulin. Therefore, it is possible that central NPY injection causes an increase in peripheral insulin and reductions in blood glucose and body heat.

In summary, central injection of NPY has an anti-stress effect and causes hypothermia in fasted chicks. I.c.v. injection of NPY affords thermotolerance, along with increased mRNA expression of HSP-70 and -90 and of NPYSRs (-Y5, -Y6, and -Y7), in heat-exposed chicks. Results obtained with the NPYSR-Y5 antagonist CGP71683 suggest that NPYSR-Y5 may partially mediate NPY-induced hypothermia. Decreased levels of plasma glucose, corticosterone, and E further suggest that central NPY may control thermal stress and body temperature to afford protective thermotolerance.

\section{Conclusions and Future Prospects}

Heat stress affects amino acid metabolic activity and neuropeptide expression in chicks. Certain amino acidsnamely, L-Cit and L-Leu-appear to be useful as biomarkers of heat stress because their concentrations are affected by heat stress, and administration of these amino acids has been found to afford thermotolerance in chicks. NPY has been considered as a food-intake regulator; however, our studies have revealed a novel role for NPY in reducing stress and body temperature in chicks under heat stress. As heat stress is a serious concern for the present and future poultry industry, our and other studies (Furukawa et al., 2015; Nanto et al., 2015; El-Deep et al., 2016; Mahmoudi et al., 2018) will contribute to overcome this serious, global challenge.

\section{Acknowledgments}

The author was awarded the 2017 Scientist Prize of the
Japan Poultry Science Association for his paper "Regulation of food intake and body temperature in heat-exposed chicks." The author expresses sincere appreciation to M. Furuse for his wholehearted support of his study on heat stress. Sincere thanks go to S. Tomonaga, K. Ito, A. Shigemura, M. A. Bahry, P. H. Do, P. V. Phuong, H. Yang, G. Han, H. M. Eltahan, T. Bungo, and all other collaborators who directly contributed to this study. Special thanks go to G. Han for careful reading of the manuscript. The author is also grateful to K. Honda, T. Ohkubo, Y. Ohta, M. Toyomizu, Y. Yoshimura, and many other renowned scientists for their constructive suggestions and encouragements. This work was supported by Grant-in-Aid for Scientific Research from the Japan Society for the Promotion of Science [grant numbers JP15K07694 and JP18K19721] and by a grant from the Kieikai 2014, 2015 Research Foundation, Japan to VSC.

\section{References}

Ajakaiye JJ, Ayo JO and Ojo SA. Effects of heat stress on some blood parameters and egg production of Shika Brown layer chickens transported by road. Biological Research, 43: 1831189. 2010.

Alldredge B. Pathogenic involvement of neuropeptides in anxiety and depression. Neuropeptides, 44: 215-224. 2010.

Asechi M, Tomonaga S, Tachibana T, Han L, Hayamizu K, Denbow DM and Furuse M. Intracerebroventricular injection of Lserine analogs and derivatives induces sedative and hypnotic effects under an acute stressful condition in neonatal chicks. Behavioural Brain Research, 170: 71-77. 2006.

Azad MA, Kikusato M, Maekawa T, Shirakawa H and Toyomizu M. Metabolic characteristics and oxidative damage to skeletal muscle in broiler chickens exposed to chronic heat stress. Comparative Biochemistry and Physiology, Part A, Molecular and Integrative Physiology, 155: 401-406. 2010.

Bahry MA, Chowdhury VS, Yang H, Tran PV, Do PH, Han G, Ikeda H, Cockrem JF and Furuse M. Central administration of neuropeptide $\mathrm{Y}$ differentially regulates monoamines and corticosterone in heat-exposed fed and fasted chicks. Neuropeptides, 62: 93-100. 2017.

Banerjee GC. In: Poultry. 3rd ed. Oxford and IBH Publishing Co. Pvt. Ltd. New Delhi, Bombay, Calcutta. pp. 104. 1998.

Bartlett JR and Smith MO. Effects of different levels of zinc on the performance and immunocompetence of broilers under heat stress. Poultry Science, 82: 1580-1588. 2003.

Bequette BJ. 2003. Amino acid metabolism in animals: an overview. In: Amino Acids in Animal Nutrition, $2^{\text {nd }}$ ed (D'mello JPE ed.). CABI Publishing, USA, pp. 87-101, 2003.

Boswell T, Dunn IC and Corr SA. Hypothalamic neuropeptide Y mRNA is increased after feed restriction in growing broilers. Poultry Science, 78: 1203-1207. 1999.

Boswell T, Millam JR, Li Q and Dunn IC. Cellular localization of neuropeptide $\mathrm{Y}$ mRNA and peptide in the brain of the Japanese quail and domestic chicken. Cell Tissue Research, 293: 31-38. 1998.

Botham KM and Mayes PA. Oxidation of fatty acids: ketogenesis. In: Harper's Illustrated Biochemistry, 30th ed. (Rodwell V, Bender D, Botham KM, Kennelly PJ, Weil PA eds.). McGrawHill Education, USA, pp. 223-244. 2015.

Brake J, Balnave D and Dibner JJ. Optimum dietary arginine: lysine ratio for broiler chickens is altered during heat stress in 
association with changes in intestinal uptake and dietary sodium chloride. British Poultry Science, 39: 639-647. 1998.

Branco LGS. Effects of 2-deoxy-D-glucose and insulin on plasma glucose levels and behavioral thermoregulation of toads. American Journal of Physiology, 272: R1-R5. 1997.

Brobeck JR. Food and temperature. Recent Progress in Hormone Research, 16: 439-466. 1960.

Buchanan TA, Cane P, Eng CC, Sipos GF and Lee CSC. Hypothermia is critical for survival during prolonged insulininduced hypoglycemia in rats. Metabolism, 40: 330-334. 1991.

Carrasco GA and Van de Kar LD. Neuroendocrine pharmacology of stress. European Journal of Pharmacology, 463: 235-272. 2003.

Catena-Dell'Osso M, Fagiolini A, Marazziti D, Baroni S and Bellantuono C. Non-monoaminergic targets for the development of antidepressants: focus on neuropeptides. Mini-Reviews in Medicinal Chemistry, 13: 2-10. 2013.

Chowdhury VS, Han G, Bahry MA, Tran PV, Do PH, Yang H and Furuse M. L-Citrulline acts as potential hypothermic agent to afford thermotolerance in chicks. Journal of Thermal Biology, 69: 163-170. 2017.

Chowdhury VS, Shigemura A, Erwan E, Ito K, Bahry MA, Tran PV and Furuse M. Oral administration of L-citrulline, but not Larginine or L-ornithine, acts as a hypothermic agent in chicks. Journal of Poultry Science, 52: 331-335. 2015.

Chowdhury VS, Tomonaga S, Ikegami T, Erwan E, Ito K, Cockrem JF and Furuse M. Oxidative damage and brain concentrations of free amino acid in chicks exposed to high ambient temperature. Comparative Biochemistry and Physiology, Part A, Molecular and Integrative Physiology, 169: 70-76. 2014.

Chowdhury VS, Tomonaga S, Nishimura S, Tabata S, Cockrem JF, Tsutsui $\mathrm{K}$ and Furuse M. Hypothalamic gonadotropin-inhibitory hormone precursor mRNA is increased during depressed food intake in heat-exposed chicks. Comparative Biochemistry and Physiology, Part A, Molecular and Integrative Physiology, 162: 227-233. 2012a.

Chowdhury VS, Tomonaga S, Nishimura S, Tabata S and Furuse M. Physiological and behavioral responses of young chicks to high ambient temperature. Journal of Poultry Science, 49: 212-218. 2012b.

Cline MA and Furuse M. Neuropeptide regulation of food intake in chicks. In: Food Intake: Regulation, Assessing and Controlling (Morrison JL ed.). NOVA Science Publishers, Inc., Hauppauge NY, USA, pp. 1-34. 2012.

Cockrem JF. Stress, corticosterone responses and avian personalities. Journal of Ornithology, 148: 169-178. 2007.

Curis E, Nicolis I, Moinard C, Osowska S, Zerrouk N, Bénazeth S and Cynober L. Almost all about citrulline in mammals. Amino Acids, 29: 177-205. 2005.

Daghir NJ. Nutrient requirements of poultry at high temperature. In: Poultry Production in Hot Climates, 2nd ed. (Daghir NJ. ed.). CABI, Wallingford, UK, pp. 132-159. 2008.

Daghir NJ, Farran MT, Barbour GW and Bexk MM. Nutritive value of high-oil corn grown under semiarid conditions and its impact on broiler performance and carcass composition. Poultry Science, 82: 267-271. 2003.

Dai SF, Gao F, Xu XL, Zhang WH, Song SX and Zhou GH. Effects of dietary glutamine and gamma-aminobutyric acid on meat colour, $\mathrm{pH}$, composition, and water holding characteristic in broilers under cyclic heat stress. British Poultry Science, 53: 471-481. 2012.

D'Allaire S, Drolet R and Brodeur D. Sow mortality associated with high ambient temperatures. Canadian Veterinary Journal, 37: 237-239. 1996.

Doerfler RE, Edens FW, Parkhurst CR, Havenstein GB and Qureshi MA. Hypothermia, hypoglycemia, and hypothyrosis associated with poult enteritis and mortality syndrome. Poultry Science, 77: 1103-1109. 1998.

Dou S, Villa-Vialaneix N, Liaubet L, Billon Y, Giorgi M, Gilbert H, Gourdine J-L, Riquet J and Renaudeau D. ${ }^{1 \mathrm{H}} \mathrm{NMR}-$ Based metabolomic profiling method to develop plasma biomarkers for sensitivity to chronic heat stress in growing pigs. PLoS ONE 12: e0188469.

El-Deep MH, Ijiri D, Ebeid TA and Ohtsuka A. Effects of dietary nano-selenium supplementation on growth performance, antioxidative status, and immunity in broiler chickens under thermoneutral and high ambient temperature conditions. Journal of Poultry Science, 53: 274-283. 2016.

Eltahan HM, Bahry MA, Yang H, Han G, Nguyen LTN, Ikeda H, Ali MN, Amber KA, Furuse M and Chowdhury VS. Central NPY-Y5 sub-receptor partially functions as a mediator of NPY-induced hypothermia and affords thermotolerance in heat-exposed fasted chicks. Physiological Reports, 5: e13511. 2017.

Ensminger ME, Oldfield JE and Heinemann WW. Feeding poultry. In: Feeds and Nutrition (2nd Edition). The Ensminger Publishing Company, Clovis, California, USA: 1009-1064. 1990.

Erwan E, Chowdhury VS, Nagasawa M, Goda R, Otsuka T, Yasuo S and Furuse M. Oral administration of D-aspartate, but not Laspartate, depresses rectal temperature and alters plasma metabolites in chicks. Life Science, 109: 65-71. 2014.

Flindt R. Amazing Numbers in Biology, 6th ed. Springer-Verlag, Berlin Heidelberg, Germany. 2002.

Franco-Jimenez DJ, Beck MM, Physiological changes to transient exposure to heat stress observed in laying hens. Poultry Science, 86: 538-544. 2007.

Freinkel N, Metzger BE, Harris E, Robinson S and Mager M. The hypothermia of hypoglycemia. New England Journal of Medicine, 287: 841-845. 1972.

Furukawa K, Kikusato M, Kamizono T, Yoshida H and Toyomizu M. Possible involvement of mitochondrial reactive oxygen species production in protein degradation induced by heat stress in avian muscle cells. Journal of Poultry Science, 52: 260-267. 2015.

Furuse M. Review: behavioral regulators in the brain of neonatal chicks. Animal Science Journal, 78: 218-232. 2007.

Furuse M, Bungo T, Ao R, Ando R, Shimojo M, Masuda Y and Denbow DM. Involvement of central gastrin and cholecystokinin in the regulation of food intake in the neonatal chick. Journal of Applied Animal Research, 18: 129-136. 2000.

Furuse M, Matsumoto M, Mori R, Sugahara K, Kano K and Hasegawa S. Influence of fasting and neuropeptide $\mathrm{Y}$ on the suppressive food intake induced by intracerebroventricular injection of glucagon-like peptide-1 in the neonatal chick. Brain Research, 764: 289-292. 1997a.

Furuse M, Matsumoto M, Saito N, Sugahara K and Hasegawa S. The central corticotropin-releasing factor and glucagon-like peptide-1 in food intake of the neonatal chick. European Journal of Pharmacology, 339: 211-214. 1997b.

Furuse M, Tachibana T, Ohgushi A, Ando R, Yoshimatsu T and Denbow DM. Intracerebroventricular injection of ghrelin and growth hormone releasing factor inhibits food intake in neonatal chicks. Neuroscience Letters, 301: 123-126. 2001. 
Gao S, Zhang J, He C, Meng F, Bu G, Zhu G, Li J and Wang Y. Molecular characterization of neuropeptide Y (NPY) receptors (Y1, Y4 and Y6) and investigation of the tissue expression of their ligands (NPY, PYY and PP) in chickens. General and Comparative Endocrinology, 240: 46-60. 2017.

Hamasu K, Haraguchi T, Kabuki Y, Adachi N, Tomonaga S, Sato H, Denbow DM and Furuse M. L-Proline is a sedative regulator of acute stress in the brain of neonatal chicks. Amino Acids, 37: 377-382. 2009a.

Hamasu K, Shigemi K, Kabuki Y, Tomonaga S, Denbow DM and Furuse M. Central L-proline attenuates stress-induced dopamine and serotonin metabolism in the chick forebrain. Neuroscience Letters, 460: 78-81. 2009b.

Hammel HT. Regulation of internal body temperature. Annual Review of Physiology, 30: 641-710. 1968.

Han G, Yang H, Bahry MA, Tran PV, Do PH, Ikeda H, Furuse M and Chowdhury VS. L-Leucine acts as a potential agent in reducing body temperature at hatching and affords thermotolerance in broiler chicks. Comparative Biochemistry and Physiology, Part A, Molecular and Integrative Physiology, 204: 48-56. 2017.

Han G, Yang H, Bungo T, Ikeda H, Wang Y, Nguyen LTN, Eltahan HM, Furuse M and Chowdhury VS. In ovo L-leucine administration stimulates lipid metabolisms in heat-exposed male, but not female, chicks to afford thermotolerance. Journal of Thermal Biology, 71: 74-82. 2018.

He C, Zhang J, Gao S, Meng F, Bu G, Li G and Wang Y. Molecular characterization of three NPY receptors (Y2, Y5 and Y7) in chickens: Gene structure, tissue expression, promoter identification, and functional analysis. General and Comparative Endocrinology, 236: 24-34. 2016.

Heilig M. The NPY system in stress, anxiety and depression. Neuropeptides, 38: 213-224. 2004.

Honda K, Saneyasu T, Hasegawa S and Kamisoyama H. A comparative study of the central effects of melanocortin peptides on food intake in broiler and layer chicks. Peptides, 37: 13-17. 2012.

Howlider MAR and Rose SP. Temperature and the growth of broilers. World's Poultry Science Journal, 43: 228-237. 1987.

Ikeda H, Kawase T, Nagasawa M, Chowdhury VS, Yasuo S and Furuse M. Metabolism of amino acids differs in the brains of Djungarian hamster ( $P$. sungorus) and Roborovskii hamster $(P$. roborovskii). SpringerPlus, 3: 277. 2014.

Ito K, Bahry MA, Hui Y, Furuse M and Chowdhury VS. Acute heat stress up-regulates neuropeptide Y precursor mRNA expression and alters brain and plasma concentrations of free amino acids in chicks. Comparative Biochemistry and Physiology, Part A, Molecular and Integrative Physiology, 187: 13-19. 2015.

Ito K, Erwan E, Nagasawa M, Furuse M and Chowdhury VS. Changes in free amino acid concentrations in the blood, brain and muscle of heat exposed chicks. British Poultry Science, 55: 644-652. 2014.

Kabuki Y, Shigemi K, Hamasu K, Denbow DM and Furuse M. Chronic L-tyrosine alters the locomotor activity and brain monoamine levels in Roborovskii hamsters. Neuroscience Letters, 488: 45-48. 2011.

Kamal R, Dutt T, Patel M, Dey A, Bharti PK and Chandran PC. Heat stress and effect of shade materials on hormonal and behavior response of dairy cattle: a review. Tropical Animal Health and Production, https://doi. org/10. 1007/s11250-0181542-6. 2018.
Kawakami S, Bungo T, Ando R, Ohgushi A, Shimojo M, Masuda Y and Furuse M. Central administration of alpha-melanocyte stimulating hormone inhibits fastingand neuropeptide Yinduced feeding in neonatal chicks. European Journal of Pharmacology, 398: 361-364. 2000.

Kormos V and Gaszner B. Role of neuropeptides in anxiety, stress, and depression: from animals to humans. Neuropeptides, 47: 401-419. 2013.

Kuenzel WJ and McMurtry J. Neuropeptide Y: brain localization and central effects on plasma insulin levels in chicks. Physiology and Behavior, 44: 669-678. 1988.

Kuenzel WJ, Douglass LW and Davison BA. Robust feeding following central administration of neuropeptide $\mathrm{Y}$ or peptide YY in chicks, Gallus domesticus. Peptides, 8: 823-828. 1987.

Kurata K, Shigemi K, Tomonaga S, Aoki M, Morishita K, Denbow DM and Furuse M. L-Ornithine attenuates corticotrophinreleasing factor-induced stress responses acting at GABAA receptors in neonatal chicks. Neuroscience, 172: 226-231. 2011.

Kurauchi I, Shigemi K, Kabuki Y, Hamasu K, Yamane H, Aoki M, Kawada Y, Morishita K, Denbow DM and Furuse M. Central L-ornithine, but not polyamines, induces a hypnotic effect in neonatal chicks under acute stress. Nutritional Neuroscience, 13: 17-20. 2010.

Li P and $\mathrm{Wu}$ G. Roles of dietary glycine, proline, and hydroxyproline in collagen synthesis andanimal growth. Amino Acids, 50: 29-38. 2018.

Liang C, Curry BJ, Brown PL and Zemel MB. Leucine modulates mitochondrial biogenesis and SIRT1-AMPK signaling in C2C12 myotubes. Journal of Nutrition and Metabolism, 239750. 2014.

Lin EJ. Neuropeptides as therapeutic targets in anxiety disorders. Current Pharmaceutical Design, 18: 5709-5727. 2012.

Lin H, Mertens K, Kemps B, Govaerts T, Deketelaere B, Debaerdemaeker J, Decuypere E and Buyse J. New approach of testing the effect of heat stress on egg quality: mechanical and material properties of eggshell and membrane. British Poultry Science, 45: 476-482. 2004.

Lindquist S. The heat-shock response. Annual Review of Biochemistry, 55: 1151-1191. 1986.

Loyau T, Métayer-Coustard S, Berri C, Crochet S, CailleauAudouin E, Sannier M, Chartrin P, Praud C, Hennequet-Antier C, Rideau N, Courousse N, Mignon-Grasteau S, Everaert N, Duchlos MJ, Yahav S, Tesseraud S and Collin A. Thermal manipulation during embryogenesis has long-term effects on muscle and liver metabolism in fast-growing chickens. PLoS ONE, 9: 1-13. 2014.

Madaan V and Wilson DR. Neuropeptides: relevance in treatment of depression and anxiety disorders. Drug News and Perspectives, 22: 319-324. 2009.

Maeda E, Kimura S, Yamada M, Tashiro M and Ohashi T. Enhanced gap junction intercellular communication inhibits catabolic and pro-inflammatory responses in tenocytes against heat stress. Journal of Cell Communication and Signaling, 11: 369-380. 2017.

Mahmoudi M, Azarfar A and Khosravinia H. Partial replacement of dietary methionine with betaine and choline in heat-stressed broiler chickens. Journal of Poultry Science, 55: 28-37. 2018.

Malva JO, Xapelli S, Baptista S, Valero J, Agasse F, Ferreira R and Silva AP. Multifaces of neuropeptide $\mathrm{Y}$ in the brain - neuroprotection, neurogenesis and neuroinflammation. Neuropeptides, 46: 299-308. 2012. 
Marsden A, Morris TR and Cromarty AS. Effects of constant environmental temperatures on the performance of laying pullets. British Poultry Science, 28: 361-380. 1987.

Mashaly MM, Hendricks GL, Kalama MA, Gehad AE, Abbas AO and Patterson $\mathrm{PH}$. Effect of heat stress on production parameters and immune responses of commercial laying hens. Poultry Science, 83: 889-894. 2004.

Matos FF, Guss V and Korpinen C. Effects of neuropeptide Y (NPY) and [DTrp32] NPY onmonoamine andmetabolite levels in dialysates fromrat hypothalamus during feeding behavior. Neuropeptides, 30: 391-398. 1996.

Mayer-Gross W and Berliner F. Observations on hypoglycemia: IV Body temperature and coma. British Journal of Psychiatry, 88: 419-427. 1942.

McConn BR, Wang G, Yi J, Gilbert ER, Osugi T, Ubuka T, Tsutsui $\mathrm{K}$, Chowdhury VS, Furuse and Cline MA. Gonadotropininhibitory hormone-stimulation of food intake is mediated by hypothalamic effects in chicks. Neuropeptides, 48: 327-334. 2014.

McConn BR, Yi J, Gilbert ER, Siegel PB, Chowdhury VS, Furuse $\mathrm{M}$ and Cline MA. 2016. Stimulation of food intake after central administration of gonadotropin-inhibitory hormone is similar in genetically selected low and high body weight lines of chickens. General and Comparative Endocrinology, 232: 96100. 2016.

Mendes AA, Watkins SE, England JA, Saleh EA, Waldroup AL and Waldroup PW. Influence of dietary lysine levels and arginine: lysine ratios on performance of broilers exposed to heat or cold stress during the period of three to six weeks of age. Poultry Science, 76: 472-481. 1997.

Moraes V, Malheiros R, Bruggeman V, Collin A, Tona K, Van As P, Onagbesan OM, Buyse J, Decuypere E and Macari M. Effect of thermal conditioning during embryonic development on aspects of physiological responses of broilers to heat stress. Journal of Thermal Biology, 28: 133-140. 2003.

Morera P, Basiricò L, Hosoda K and Bernabucci U. Chronic heat stress up-regulates leptin and adiponectin secretion and expression and improves leptin, adiponectin and insulin sensitivity in mice. Journal of Molecular Endocrinology, 48: 129-138. 2012.

Nanto F, Ito C, Kikusato M and Toyomizu M. Effects of wholegrain paddy rice on growth performance, oxidative stress and morphological alterations of the intestine in broiler chickens exposed to acute and chronic heat stress. Journal of Poultry Science, 52: 109-118. 2015.

National Aeronautics and Space Administration (NASA). https:// climate.nasa.gov/news/2671/long-term-warming-trend-continuedin-2017-nasa-noaa/

Nyachoti CM, Zijlstra RT, de Lange CFM and Patience JF. Voluntary feed intake in growing-finishing pigs: A review of the main determining factors and potential approaches for accurate predictions. Canadian Journal of Animal Science. 84: 549566. 2004.

Nishizawa N. Development and its application of a method to estimate catabolic rate of myofibrillar proteins by measuring urinary excretion of N-methylhistidine. Journal of Nutritional Science and Vitaminology (Tokyo), 36: 409-423. 1983.

Niu Z, Liu F, Yan Q and Li L. Effects of different levels of selenium on growth performance and immunocompetence of broilers under heat stress. Archives of Animal Nutrition, 63: 56-65. 2009.

Palmer RMJ, Ferrige AG and Moncada S. Nitric oxide release accounts for the biological activity of endothelium-derived relaxing factor. Nature, 237: 524-526. 1987.

Peguri A and Coon C. Effect of temperature and dietary energy on layer performance. Poultry Science, 70: 126-138. 1991.

Quiniou N and Noblet J. Influence of high ambient temperatures on performance of multiparous lactating sows. Journal of Animal Science, 77: 2124-2134. 1999.

Reichmann F and Holzer P. Neuropeptide Y: a stressful review. Neuropeptides, 55: 99-109. 2016.

Rocha PL and Branco LGS. Physiological significance of behavioral hypothermia in hypoglycemic frogs (Rana catesbeiana). Comparative Biochemistry and Physiology, Part A, Molecular and Integrative Physiology, 119: 957-961. 1998.

Rose SP and Uddin MS. Effect of temperature on the responses of broiler chickens to dietary lysine balance. British Poultry Science, 38: S36-S37. 1997.

Sabban EL, Alaluf LG and Serova LI. Potential of neuropeptide Y for preventing or treating post-traumatic stress disorder. Neuropeptides, 56: 19-24. 2016.

Saito ES, Kaiya H, Takagi T, Yamasaki I, Denbow DM, Kangawa K and Furuse M. Chicken ghrelin and growth hormone-releasing peptide-2 inhibit food intake of neonatal chicks. European Journal of Pharmacology, 453: 75-79. 2002.

Schank JR, Ryabinin AE, Giardino WJ, Ciccocioppo R and Heilig M. Stress related neuropeptides and addictive behaviors: beyond the usual suspects. Neuron, 76: 192-208. 2012.

Seal CJ and Parker DS. Inter-organ amino acid flux. In: Farm Animal Metabolism and Nutrition (D'Mello JPF ed.). CAB International, Wallingford, UK, pp. 49-63. 2000.

Siegel HS. Stress, strains and resistance. British Poultry Science, 36: 3-20. 1995.

Soleimani AF, Kasim A, Alimon AR, Meimandipour A and Zulkifli I. Ileal endogenous amino acid flow of broiler chickens under high ambient temperature. Journal of Animal Physiology and Animal Nutrition (Berl), 94: 641-647. 2010.

Song Z, Liu L, Sheikhahmadi A, Jiao H and Lin H. Effect of heat exposure on gene expression of feed intake regulatory peptides in laying hens. Journal of Biomedicine and Biotechnology, 2012: 484869. 2012.

Sterling KG, Bell DD, Pesti GM and Aggrey SE. Relationships among strain, performance, and environmental, temperature in commercial laying hens. Journal of Applied Poultry Research, 12: 85-91. 2003.

Suenaga R, Yamane H, Tomonaga S, Asechi M, Adachi N, Tsuneyoshi Y, Kurauchi I, Sato H, Denbow DM and Furuse M. Central L-arginine reduced stress responses are mediated by Lornithine in neonatal chicks. Amino Acids, 35: 107-113. 2008.

Szabo C. Physiological and pathophysiological roles of nitric oxide in the central nervous system. Brain Research Bulletin, 41: 131-141. 1996.

Szekely M, Petervari E and Szelenyi Z. Orexigenic vs. anorexigenic peptides and feeding status in the modulation of fever and hypothermia. Frontiers in Bioscience, 9: 2746-2763. 2004.

Tachibana T, Sato M, Oikawa D, Takahashi H, Boswell T and Furuse M. Intracerebroventricular injection of neuropeptide $\mathrm{Y}$ modifies carbohydrate and lipid metabolism in chicks. Regulatory Peptides, 136: 1-8. 2006.

Tachibana T, Sato M, Takahashi H, Ukena K, Tsutsui K and Furuse M. Gonadotropin-inhibiting hormone stimulates feeding behavior in chicks. Brain Research, 1050: 94-100. 2005.

Tamir H and Ratner S. Enzymes of arginine metabolism in chicks. Archives of Biochemistry and Biophysics, 102: 249-258. 
1963.

Tan CL, Cooke EK, Leib DE, Lin YC, Daly GE, Zimmerman CA and Knight ZA. Warm-Sensitive Neurons that Control Body Temperature. Cell, 167: 47-59. 2016.

Thaxton P. Wyatt RD and Hamilton PB. The effect of environmental temperature on paratyphoid infection in the neonatal chicken. Poultry Science, 53: 88-94. 1974.

Tran PV, Chowdhury VS, Do PH, Bahry MA, Yang H and Furuse M. L-Ornithine is a potential acute satiety signal in the brain of neonatal chicks. Physiology and Behavior, 155: 141-148. 2016.

Tran PV, Chowdhury VS, Nagasawa M and Furuse M. Changes in free amino acid and monoamine concentrations in the chick brain associated with feeding behavior. SpringerPlus, 4: 252. 2015.

Voet D and Voet JG. Biochemistry, 2nd ed. John Wiley \& Sons, Inc, USA. 1995.

Wang Q, Wang M and Whim MD. Neuropeptide Y gates a stressinduced, long-lasting plasticity in the sympathetic nervous system. Journal of Neuroscience, 33: 12705-12717. 2013.

Webb P. Continuous measurement of heat loss and heat production and the hypothesis of heat regulation. In: Thermoregulation (Blatteis CM ed.). The New York Academy of Sciences, New York, pp. 12-20. 1997.

Willemsen H, Swennen Q, Everaert N, Geraert PA, Mercier Y,
Stinckens A, Decuypere E and Buyse J. Effects of dietary supplementation of methionine and its hydroxy analog DL-2hydroxy-4-methylthiobutanoic acid on growth performance, plasma hormone levels, and the redox status of broiler chickens exposed to high temperatures. Poultry Science, 90: 23112320. 2011.

Windmueller HG and Spaeth AE. Source and fate of circulating citrulline. American Journal of Physiology, 241: 473-480. 1981.

Yahav S. Regulation of body temperature: strategies and mechanisms. In: Sturkie's Avian Physiology, 6th ed (Scanes CG ed.). Academic Press, London, UK, pp. 869-905. 2015.

Yahav S and Hurwitz S. Induction of thermotolerance in male broiler chickens by temperature conditioning at an early age. Poultry Science, 75: 402-406. 1996.

Yahav S, Shinder D, Razpakovski V, Rusal M and Bar A. Lack of response of laying hens to relative humidity at high ambient temperature. British Poultry Science, 41: 660-663. 2000.

Young VR and Munro HN. Ntau-methylhistidine (3-methylhistidine) and muscle protein turnover: an overview. Federation Proceedings, 37: 2291-2300. 1978.

Zhang R, Tachibana T, Takagi T, Koutoku T, Denbow DM and Furuse M. Centrally administered norepinephrinemodifies the behavior induced by corticotropin-releasing factor in neonatal chicks. Journal of Neuroscience Research, 74: 630-636. 2003. 